\title{
Diet shifts and population dynamics of estuarine foraminifera during ecosystem recovery after experimentally induced hypoxia crises
}

\author{
G.M. Brouwer ${ }^{\text {a, }}$, I.A.P. Duijnstee ${ }^{\text {a, b, c }}$, J.H. Hazeleger ${ }^{\text {a }}$, F. Rossi ${ }^{\text {d, e }}$, L.J. Lourens ${ }^{\text {a }}$, \\ J.J. Middelburg ${ }^{\mathrm{a}, \mathrm{e}}$, M. Wolthers ${ }^{\mathrm{a}, \mathrm{f}}$ \\ ${ }^{a}$ Utrecht University, Faculty of Geosciences, Department of Earth Sciences, P.O. Box 80.021, 3584 TA Utrecht, The Netherlands \\ ${ }^{\mathrm{b}}$ University of California, Berkeley, Department of Integrative Biology, Berkeley, CA 94720, USA \\ ${ }^{\mathrm{c}}$ University of California Museum of Paleontology, Berkeley, CA 94720, USA \\ ${ }^{\mathrm{d}}$ UMR 5119-Ecosym, CNRS-IRD-IFREMER-Université Montpellier 2, 34095 Montpellier Cedex 5, France \\ e Department of Ecosystem Studies, Royal Netherlands Institute for Sea Research, Yerseke, The Netherlands \\ ${ }^{\mathrm{f}}$ University College London, Department of Chemistry, 20 Gordon Street, London WC1H 0AJ, United Kingdom
}

\section{A R T I C L E I N F O}

\section{Article history:}

Received 26 September 2013

Received in revised form

27 November 2015

Accepted 12 December 2015

Available online 20 December 2015

\section{Keywords:}

Intertidal

Benthic foraminifera

Hypoxia

${ }^{13} \mathrm{C}$ label

Diet shifts

Population dynamics

\begin{abstract}
A B S T R A C T
This study shows foraminiferal dynamics after experimentally induced hypoxia within the wider context of ecosystem recovery. ${ }^{13} \mathrm{C}$-labeled bicarbonate and glucose were added to the sediments to examine foraminiferal diet shifts during ecosystem recovery and test-size measurements were used to deduce population dynamics. Hypoxia-treated and undisturbed patches were compared to distinguish natural (seasonal) fluctuations from hypoxia-induced responses. The effect of timing of disturbance and duration of recovery were investigated. The foraminiferal diets and population dynamics showed higher fluctuations in the recovering patches compared to the controls. The foraminiferal diet and population structure of Haynesina germanica and Ammonia beccarii responded differentially and generally inversely to progressive stages of ecosystem recovery. Tracer inferred diet estimates in April and June and the two distinctly visible cohorts in the test-size distribution, discussed to reflect reproduction in June, strongly suggest that the ample availability of diatoms during the first month of ecosystem recovery after the winter hypoxia was likely profitable to $A$. beccarii. Enhanced reproduction itself was strongly linked to the subsequent dietary shift to bacteria. The distribution of the test dimensions of $\mathrm{H}$. germanica indicated that this species had less fluctuation in population structure during ecosystem recovery but possibly reproduced in response to the induced winter hypoxia. Bacteria seemed to consistently contribute more to the diet of H. germanica than diatoms. For the diet and test-size distribution of both species, the timing of disturbance seemed to have a higher impact than the duration of the subsequent recovery period.
\end{abstract}

() 2016 Published by Elsevier Ltd.

\section{Introduction}

Coastal areas provide many resources and services beneficial to human settlement. These favorable conditions in near-coastal zones have led to human population densities nearly three times higher than the global average (Small and Nicholls, 2003). High population densities in coastal zones make these areas more prone to anthropogenic perturbations (Diaz et al., 2009 and references

\footnotetext{
* Corresponding author.

E-mail addresses: Brouwer.margreet@gmail.com (G.M. Brouwer), duijnstee@ berkeley.edu (I.A.P. Duijnstee), jhhazeleger@gmail.com (J.H. Hazeleger), francesca. rossi@univ-montp2.fr (F. Rossi), L.J.Lourens@uu.nl (L.J. Lourens), J.B.M. Middelburg@uu.nl (J.J. Middelburg), m.wolthers@uu.nl (M. Wolthers).
}

therein). Consequences of such perturbations, as for example instances of low-oxygen concentrations in bottom waters, cause a loss of ecosystem services (Diaz and Rosenberg, 2008 and references therein). Hypoxia induced stress may alter species behavior and provoke mortality of sensitive species (as reviewed by e.g. Gray et al., 2002; Zhang et al., 2009; Diaz et al., 2009). These alterations affect food-web interactions and the functioning of estuarine communities (Conley et al., 2007; Diaz et al., 2009).

In order to be able to protect and restore complex coastal ecosystems, explicit knowledge on their functioning is required. The use of selected species as indicator for ecosystem functioning can be very helpful to more easily monitor ecosystem development. Among the benthic fauna in estuarine ecosystems, foraminiferal species are increasingly recognized as efficient ecological indicators 
(Debenay et al., 2006; Schönfeld et al., 2012; Bouchet et al., 2012; Brouwer et al., 2015; Strotz, 2015).

Foraminifera are common marine heterotrophic unicellular bikont eukaryotes from the supergroup Rhizaria; several characteristics favor their applicability as indicator species. Foraminifera have a small sized test and are densely present in most marine sediments. Hence, limited volumes of relatively easily collectable sediment suffice for an accurate study of foraminiferal dynamics. Furthermore, foraminifera generally possess a high ability to survive perturbations, so they may record the higher end of the disturbance spectrum, long after macrofauna have succumbed (Josefson and Widbom, 1988; Langlet et al., 2014). Notwithstanding their high potential to survive disturbance, foraminiferal populations commonly respond fast to changes in their environment (e.g. Jorissen et al., 1995; Debenay et al., 2006; Denoyelle et al., 2010). Especially fluctuations in the availability of oxygen and food are considered to structure benthic foraminiferal communities and their spatial distribution (Jorissen et al., 1995; Van der Zwaan et al., 1999).

Within the food web, foraminifera reside in an intermediate position in-between microbes and macrofauna and occupy a variety of trophic niches. Several foraminiferal feeding strategies have been described (e.g. Lipps, 1983). Some species have been reported to graze on diatoms or other algae, while others use their pseudopodia to trap detritus or even metazoans. Besides parasitism, carnivory, bacterivory and cannibalism, foraminiferal symbiotic trophic relationships with bacteria and algae have been observed (Goldstein 1999 and references therein). Hypoxic disturbance may alter the availability and composition of food resources and influence foraminiferal carbon utilization (e.g. Gustafsson and Nordberg, 2000).

Pulses of organic matter and oxygen depletion affect foraminiferal densities and migratory behavior; these responses are species-specific (Ernst et al., 2005) and variable effects can be observed in different foraminiferal size classes because of altered population dynamics and life-history strategies (Duijnstee et al., 2005). Duijnstee et al. (2005) observed that a pulse of organic matter, provoking anoxic conditions, inhibited foraminiferal growth, but enhanced fecundity and likely triggered reproduction at a very early stage. The foraminiferal test size and the foraminiferal fecundity are also related to the availability of specific food sources (e.g., Muller and Lee, 1969; Parfrey and Katz, 2010). For instance, Muller and Lee (1969) reported that some foraminifera require bacteria to sustain reproduction. Parfrey and Katz (2010) discovered that specimens of the foraminifer Allogromia laticollaris that foraged on a mixture of algae and bacteria had a higher number of offspring compared to specimens feeding on bacteria only. In consequence, hypoxia can alter foraminiferal assemblages because of their species-specific tolerance for oxygen depletion, as well as assemblage composition through its impact on food availability and food web interactions.

The main question addressed in this study is how ecosystem recovery after hypoxia influences the dynamics of foraminiferal species; i.e. their population structures (e.g. size distribution, survival, growth and reproduction) and feeding strategies. By disentangling the impact of ecosystem properties, such as food availability and macro- and meiofaunal presence, on foraminiferal feeding and population dynamics in disturbed and undisturbed ecosystems, the accurate use of foraminifera as indicator species for monitoring ecosystem functioning can be improved. To address these objectives, sediments of an intertidal flat in the Scheldt Estuary on the Dutch coast were in situ exposed to human-induced hypoxia in winter or late spring. To study the carbon flow from micro-organisms at the base of the food web - such as diatoms and heterotrophic bacteria - to the dominant foraminiferal species
Ammonia beccarii and Haynesina germanica, ${ }^{13} \mathrm{C}$-labeled glucose and bicarbonate were introduced in these in situ experiments to enrich heterotrophic bacteria and benthic algae, respectively (Rossi et al., 2009). To investigate the effect of ecosystem recovery following hypoxia on foraminiferal population dynamics, we analyzed the distribution of test sizes combined with food consumption patterns of foraminifera at different times in a 5-month period of ecosystem recovery. These observations were compared to simultaneous observations from undisturbed (control) sediments where no hypoxia occurred. Comparing foraminiferal dynamics (e.g., population dynamics and diet shifts) among hypoxiadisturbed and undisturbed sediments provide the opportunity to discriminate between the natural, seasonal development of the ecosystem (due to e.g. variations in temperature, day length, larval availability etc.) and the influence of ecosystem recovery following hypoxia.

Previous work on the same set of field experiments has shown that the timing of experimentally-induced disturbance lead to differential responses in ecosystem properties that are subsequently assumed to directly or indirectly influence foraminifera e.g. via differential alterations of food availability (Brouwer et al., 2015), or differences in predation pressure and disturbance effects of recovering nematodes and macrofauna (see Montserrat et al., 2008, 2009; Van Colen et al., 2008, 2009, 2010a, b, 2012; Rossi et al., 2008, 2009; Rossi and Middelburg 2011). These hypoxia-related changes in ecosystem properties and the direct impact of hypoxia on foraminifera determine the net impact of hypoxia on foraminifera. Hence, our results will be discussed in the context of findings published in these parallel studies.

\section{Material and methods}

The field experiments took place on a tidal flat bordering the Paulina Polder on the southern bank of the Scheldt Estuary in the Netherlands $\left(51^{\circ} 21^{\prime} 23^{\prime \prime} \mathrm{N}, 3^{\circ} 42^{\prime} 49^{\prime \prime} \mathrm{E}\right.$, Fig. 1). The mudflat covers an area of around $1.0 \mathrm{~km}^{2}$, it has a mean tidal range of $3.9 \mathrm{~m}$ with a semidiurnal regime and a yearly average salinity of 24 (Van Colen et al., 2012). Under natural conditions, the macrofaunal community is dominated by polychaetes (Heteromastus filiformis, Arenicola marina, Pygospio elegans) and mollusks (Macoma balthica, Cerastoderma edule, Hydrobia ulvae) (Rossi et al., 2009). For food supply, this community of macrofaunal invertebrates relies of phytodetritus and autotrophs within the sediments such as microphytobenthos and chemo-autotrophic bacteria. This carbon can be transferred to the meiofaunal community of (predominantly) nematodes (e.g., Daptonema spp., Chromadora spp., Anoplostoma viviparum, Oncholaimellus sp.1., Viscosia spp. and Ptycholaimellus ponticus; Van Colen et al., 2009), foraminifera (H. germanica, A. beccarii and Elphidium excavatum; Brouwer et al., 2015) and macrofauna (Rossi et al., 2009). Heterotrophic bacteria utilize carbon from each trophic level and may return carbon to the system as food source especially for the meiofaunal part of the system.

\subsection{Experimental set-up: labeling and sampling}

Hypoxic conditions were experimentally induced twice: once in winter and once in late spring. To this end, two large patches $(4 \times 4$ meter) within a $50 \times 50 \mathrm{~m}$ location (Figs. 1 and 2) were covered for two months with black waterproof polyethylene sheets - both stopping oxygenic photosynthesis and effectively preventing the replenishment of oxygen that was consumed during decomposition of the ample organic matter content of the sediment, and thus rendering the sediment hypoxic. The first hypoxic period lasted from January $30^{\text {th }}$ until March $30^{\text {th }} 2005$ and the second from May 9th until July 6th 2005 (Fig. 3). During both periods, two 


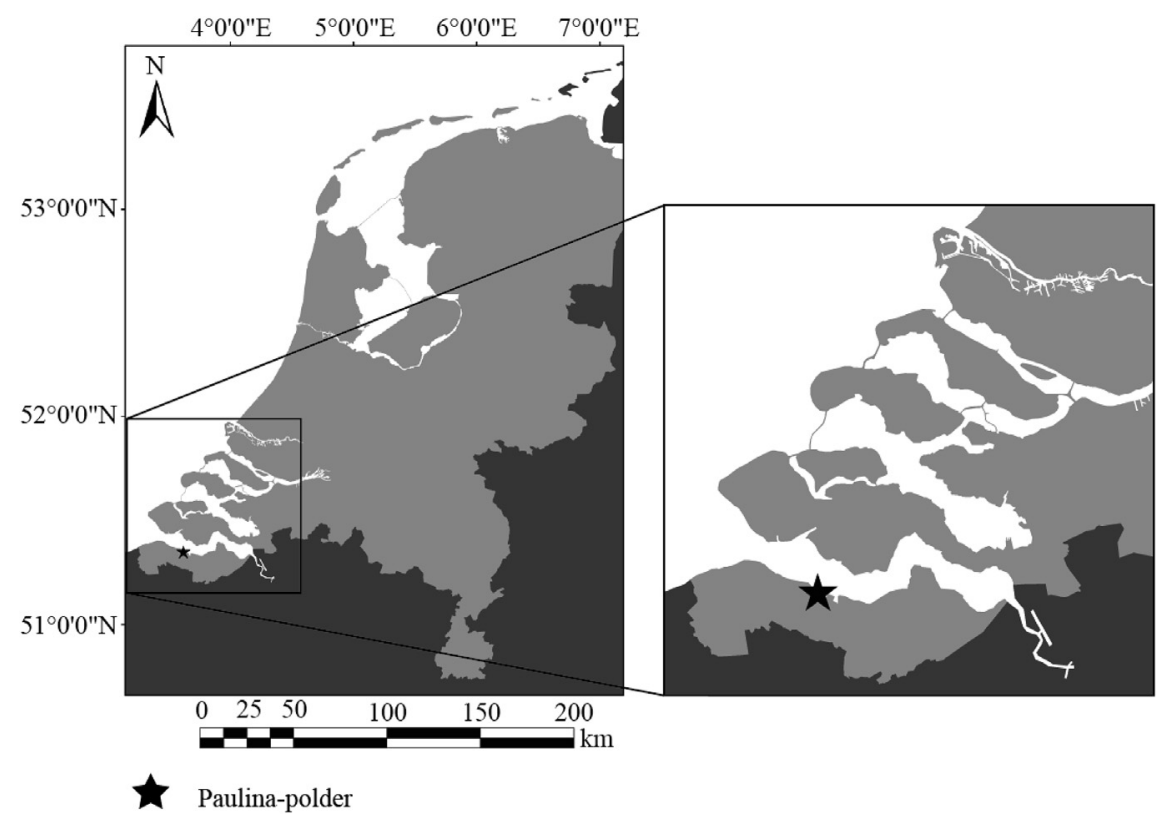

Fig. 1. Map of the Scheldt Estuary.

undisturbed sediment patches $(4 \times 4$ meter) were used as controls. In the same area multiple patches were similarly treated and used in parallel studies to investigate macrofaunal recolonization, sediment characteristics and carbon cycling from microbes to macrofauna (Van Colen et al., 2008, 2009, 2010a, b, 2012; Rossi et al., 2009 and Rossi and Middelburg 2011).

After removal of the plastic sheets, oxygen concentrations in the top layer of the sediment re-established within a few days (Van Colen et al., 2012). In April $\left(10^{\circ} \mathrm{C}\right)$, twelve days after removal of the plastic sheets that had induced the winter hypoxia, sediment was collected in the hypoxia-treated patches for a field observation on foraminiferal abundances $(0 \mathrm{~A})$. Subsequent to the field observation, the sediment patches were left to recover for nearly two months. Samples for foraminiferal and microbial analyses were taken in June $\left(13{ }^{\circ} \mathrm{C} ; 2 \mathrm{~J}\right)$ and September $\left(20^{\circ} \mathrm{C} ; 5 \mathrm{~S}\right)$ in patches exposed to the winter hypoxia. The two-character coding (Fig. 3) used throughout the text refers to control $(C)$ or months of recovery $(0,2,5)$ and month of sampling $(\mathrm{A}, \mathrm{J}, \mathrm{S})$. The patches that endured a spring hypoxia were sampled in September (2S). In June (CJ) and September (CS) samples were taken in the control patches (see sampling scheme, Fig. 3). During low tide, $96 \mathrm{~h}$ preceding each sample occasion the hypoxia-affected and the undisturbed control patches were treated with the addition of ${ }^{13} \mathrm{C}$-labeled glucose or ${ }^{13}$ C-labeled bicarbonate (see Rossi et al., 2009 and Rossi and Middelburg, 2011). To this end, four plots of $0.5 \times 0.5 \mathrm{~m}$ were selected within each patch. Half of these plots were supplied with $250 \mathrm{mg}$ of ${ }^{13} \mathrm{C}$-labeled bicarbonate $\left(99 \%{ }^{13} \mathrm{C}\right)$, and the other half with $114.75 \mathrm{mg}{ }^{13} \mathrm{C}$-labeled glucose $\left(99 \%{ }^{13} \mathrm{C}\right)$; both dissolved in $250 \mathrm{ml}$ of filtered seawater. The timing and amount of added label was chosen based on previous studies (Middelburg et al., 2000; Van Oevelen et al., 2006). The ${ }^{13} \mathrm{C}$-labeled bicarbonate was intended to be used by microphytobenthos in photosynthesis, and therefore
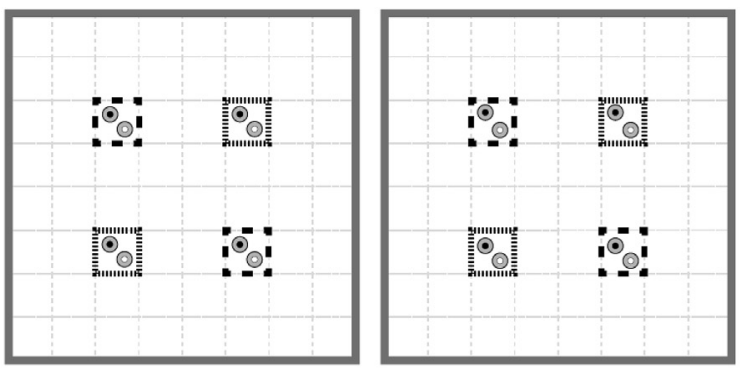

2 Patches $4 \times 4$ m each, per treatment and sample occassion

2 plots $(0.5 \times 0.5 \mathrm{~m})$ per patch treated with ${ }^{13} \mathrm{C}$ labeled glucose

. 2 plots $(0.5 \times 0.5 \mathrm{~m})$ per patch treated with ${ }^{13} \mathrm{C}$ labeled bicarbonate

- 8 cores $\varnothing 5 \mathrm{~cm}$ for macrofaunal analyzes, with 1 subsample $\varnothing 2 \mathrm{~cm}$ for foraminifera

(-) 8 cores $\varnothing 5 \mathrm{~cm}$ for macrofaunal analyzes, with 1 subsample $\emptyset 2 \mathrm{~cm}$ for meiofauna other than foraminifera

Fig. 2. Schematic overview of sampling design. 

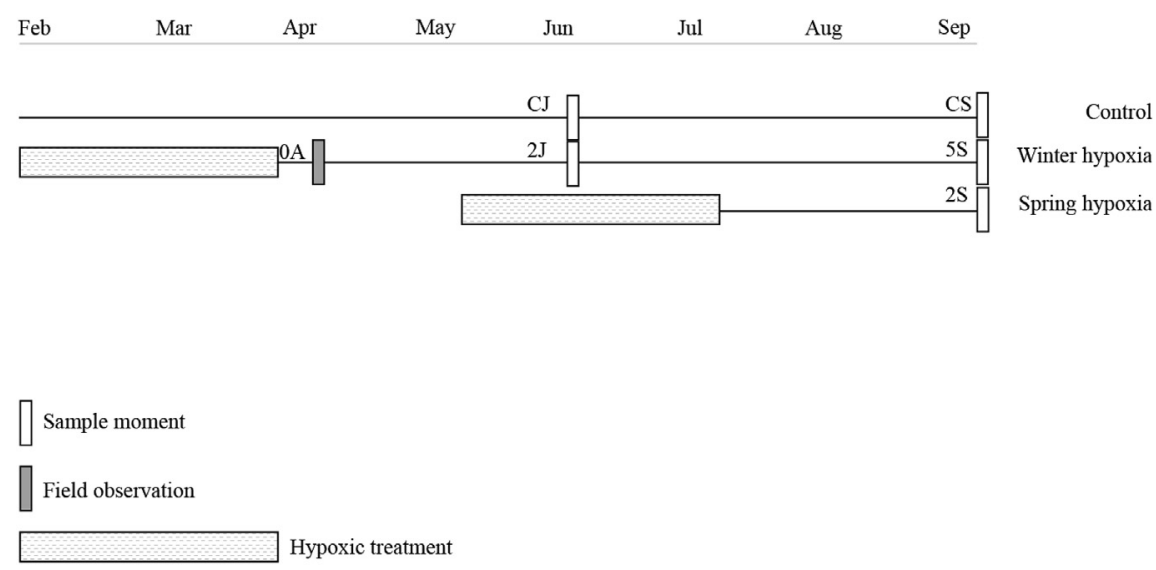

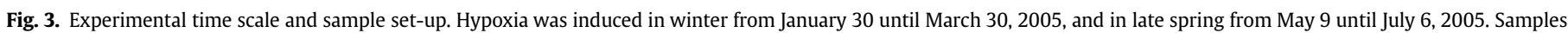
were taken on June 10 and September 9, 2005.

sprayed on top of the sediment. The addition of ${ }^{13} \mathrm{C}$-labeled glucose was aimed to label heterotrophic bacteria living both on and in the sediment. The glucose was injected into the top $8 \mathrm{~cm}$ of the sediment. To equally spread the labeled glucose, injections were homogenized over the surface with a grid of $2.5 \times 2.5 \mathrm{~cm}$ holes (see Van Oevelen et al., 2006 for details). Sampling was done $96 \mathrm{~h}$ after the addition of labeled carbon. Two cores ( $5 \mathrm{~cm}$ internal diameter) were taken to $8 \mathrm{~cm}$ sediment depth in each plot (Fig. 2; see also Rossi et al., 2009). In the laboratory the cores were subsampled, and the top one centimeter was used for biomass and ${ }^{13} \mathrm{C}$ incorporation of microbes and foraminifera using a cut syringe with an internal diameter of $2 \mathrm{~cm}$ (analyzed volume $3.14 \mathrm{~cm}^{3}$ per sample). For microbial analyses, phospholipid-derived fatty acid (PLFA) biomarkers - the lipids composing organisms cell membrane are group specific - were extracted from $3 \mathrm{~g}$ of dry sediment using Bligh and Dyer extraction (details in Rossi et al., 2009). The bacterial-specific PLFA biomarkers 14:0 iso, 15:0 iso, 15:0 anteiso and 16:0 iso as well as the diatom PLFA 20:5w3 were used to trace label incorporation and diatom and bacterial biomass (Rossi and Middelburg, 2011).

\subsection{Sample processing}

The sediment samples used for foraminiferal analyses were stored in $4 \%$ buffered formalin with Rose Bengal staining. Although formalin may slightly alter the isotopic composition, this effect can be ignored in tracer applications (Rossi and Middelburg, 2011). After foraminiferal cytoplasm was stained, the sediment samples were sieved over a mesh size of $63 \mu \mathrm{m}$. Well-stained foraminifera were picked from the wet residues and enumerated at species level. Only individuals fully filled with vividly pink stained cytoplasm (except for the ultimate chamber) were considered alive close to the time of sampling. After picking, photos were taken with a Hitachi Camera, type Hv-c20A mounted on a (Leica MZ12(5)) microscope with a calibrated internal scale to measure the maximum test dimension of each individual specimen. In order to analyze the distribution of test dimensions, foraminiferal individuals were binned in 10 size classes of $39 \mu \mathrm{m}$ for $H$. germanica and $56 \mu \mathrm{m}$ for $A$. beccarii. The smallest size class starts with $63-102 \mu \mathrm{m}$ for $H$. germanica and 63-119 $\mu \mathrm{m}$ for $A$. beccarii; species-specific bin sizes were used for optimal distribution of the test-size dimension of both species. The test-size frequency was expressed as a percentage of the total population (per species, sample moment and treatment) found in a size bin. In addition, each size measurement was used to calculate individual foraminiferal biovolume. The maximum test-size dimension (L) was used to estimate the foraminiferal biovolume of each individual (BV), using the equation $\mathrm{BV}=\pi \mathrm{L}^{3} / 16$ (this is the volume of a disk with diameter $\mathrm{L}$ and a height of $0.25 \mathrm{~L}$ ). Subsequently, the individual biovolumes were used to obtain the individual biomasses. Moodley et al. (2000) reported for the species $A$. beccarii an average individual biomass of $1.10 \mu \mathrm{gC} /$ individual to co-occur with an average length of $325 \mu \mathrm{m}$ and for $\mathrm{H}$. germanica an average biomass of $1.48 \mu \mathrm{gC} /$ individual to co-occur with an average length of $381 \mu \mathrm{m}$. These values were used to convert the individual biovolumes of both species to individual biomasses. The individual biomasses were required to semiquantitatively derive the transfer of carbon from microbes to foraminifera.

To analyze the uptake of labeled carbon by both foraminiferal species, stained specimens were randomly selected, rinsed with Milli-Q to remove debris and placed in silver boots (see Moodley et al., 2000 for processing details). Each sample contained 20 to 100 specimens depending on their individual sizes selected to obtain samples similar in biomass. To remove the foraminiferal tests $50 \mu \mathrm{l}$ of $2.5 \% \mathrm{HCl}$ was added to dissolve the carbonate. The completeness of decalcification of the foraminiferal test was visually checked and an extra (50 $\mu \mathrm{l} 2.5 \%) \mathrm{HCL}$ was added in case of incomplete decalcification. The samples were dried and concentrations of carbon isotopes were measured using a Carlo Erba 1106 Elemental Analyzer coupled online with a Finnigan Delta $S$ isotope ratio mass spectrometer. The incorporation of label in microbes and foraminifera was used to determine foraminiferal diets as well as the contribution of foraminifera to the transfer of microbial carbon through the foodweb (after Moodley et al., 2000).

\subsection{Label incorporation - foraminiferal diets ( $\Delta$-ratios)}

The relative importance of bacteria and diatoms as food source for foraminifera was quantified by the $\Delta$-ratio, the fraction of the total carbon in the consumer that is derived from either bacteria or diatoms (see Van Oevelen et al., 2006; Rossi and Middelburg, 2011). The diets, i.e. $\Delta$-ratios, were determined for both foraminiferal species using the equations:

$\Delta$-ratio foraminifera/microbe $=\left(\Delta \delta^{13} C_{\text {foraminifera }} / \Delta \delta^{13} C_{\text {microbe }}\right)$

The incorporation of ${ }^{13} \mathrm{C}$ label in foraminifera and microbes is expressed as $\Delta \delta^{13} \mathrm{C}$ (Middelburg, 2014):

$\Delta \delta^{13} \mathrm{C}=\delta^{13} \mathrm{C}_{\text {sample }}-\delta^{13} \mathrm{C}_{\text {background }}$ 
The $\Delta \delta^{13} \mathrm{C}$ of the foraminifera and the microbes is the difference in label enrichments between samples derived from the experimental patches (all treated with either the addition of ${ }^{13} \mathrm{C}$-labeled glucose or ${ }^{13} \mathrm{C}$-labeled bicarbonate) and natural enrichment in ${ }^{13} \mathrm{C}$ of the background. The $\delta^{13} \mathrm{C}$ of the foraminifera and the microbes from treated patches and background values are both expressed as relative deviation $\left(\delta^{13} \mathrm{C}\right.$ in \%o from the ratio $\left({ }^{13} \mathrm{C} /{ }^{12} \mathrm{C}\right)$ in the Vienna Pee Dee Belemnite standard (VPDB). The $\Delta$-ratios were estimated to infer diet shift during ecosystem recovery.

The bacterial $\Delta \delta^{13} \mathrm{C}$ was calculated as weighted average based on the label incorporation and the concentration of each of the bacterial-specific PLFA's biomarkers extracted from dry sediment and the diatom $\Delta \delta^{13} \mathrm{C}$ was determined using the label incorporation and concentration of the diatom-specific PLFA 20:5w3 (for details see: Middelburg et al., 2000). The $\Delta \delta^{13} \mathrm{C}$ of the foraminiferal species were established directly from the foraminiferal flesh (see above). Background values of $-16.6 \%$ and $-12.9 \%$ were respectively used for $A$. beccarii and $H$. germanica (after Moodley et al., 2000). By using these equations, we assumed a steady state between $\Delta \delta^{13} \mathrm{C}_{\text {consumer }}$ and $\Delta \delta^{13} \mathrm{C}_{\text {resource. In correspondence with Van }}$ Oevelen et al. (2006) and Middelburg (2014) we used this equation because label incorporation was not measured in time series necessary to estimate carbon flow via the (more accurate) isotope model.

\subsection{Label incorporation - carbon transfer}

The measured incorporation of label in the foraminifers and the microbes was also used to semi-quantitatively estimate the transfer of carbon from microbes to foraminifera. To determine this transfer of carbon, the relative uptake of label $(I)$ by foraminifera $\left(I_{\text {foraminifera }}\right)$ was expressed as a percentage of the label uptake by bacteria ( $\left.I_{\text {bacteria }}\right)$ and diatoms $\left(I_{\text {diatom }}\right)$. Label uptake by foraminifera and microbes was calculated as the product of excess $(E)$ and foraminiferal biomass or microbial PLFA carbon. The average microbial biomasses have been published by Rossi et al., 2009 (Table 1). The foraminiferal biomasses were calculated based on the measured biovolumes (see paragraph 2.2). Total incorporation of ${ }^{13} \mathrm{C}$ is excess $(E)$ multiplied by the total biomass per standardized sample volume. $E$ can be calculated by taking the difference between the ${ }^{13} \mathrm{C}$ fractions $(F)$ of biota (e.g. foraminifera) from sediments treated with label and those from non-labeled background sediments (or: $\left.E=F_{\text {treated }}-F_{\text {background }}\right)$. In turn, $F$ is defined as $R_{\text {sample }} /\left(R_{\text {sample }}+1\right)$, where $R_{\text {sample }}$ is the isotope ratio $\left({ }^{13} \mathrm{C} /{ }^{12} \mathrm{C}\right)$ sample which can be derived from our $\delta^{13} \mathrm{C}$ values as follows: $R_{\text {sample }}=R_{\mathrm{VPDB}}\left(\left[\delta^{13} \mathrm{C} /\right.\right.$ $1000]+1)$. Combining the above with an estimate for $R_{\mathrm{VPDB}}$ of 0.0112372 (after Middelburg et al., 2000; Moodley et al., 2002) yields the following equation for $E$ :

$E=\frac{\delta^{13} C_{\text {sample }}+1000}{\delta^{13} C_{\text {sample }}+91909}-\frac{\delta^{13} C_{\text {control }}+1000}{\delta^{13} C_{\text {control }}+91909}$

$I_{\text {foraminifera }}$ can now be obtained by multiplying $E$ with the estimated biomass of the foraminiferal flesh. Label uptake into bacteria and diatoms was analyzed using PLFA's biomarkers extracted from dry sediments samples. Ibacteria was estimated as:

$I_{\text {bacteria }}=\Sigma I_{\text {PLFAbacteria }} / a^{*} b$.

where $a$ is the estimated contribution of the measured bacterial PLFA biomarkers to the total bacterial PLFA content $(\approx 0.14$, after Moodley et al., 2002), and $b$ is the contribution of carbon in bacterial PLFAs to the total bacterial carbon content $\left(\approx 0.056 \mathrm{gC}_{\mathrm{PLFA}}\right)$ $\mathrm{gC}_{\text {bacteria, }}$ after Middelburg et al., 2000).

Similarly, label uptake by algae $\left(I_{\text {diatom }}\right)$ was estimated as:

$I_{\text {diatom }}=I_{\mathrm{PLFA} 20: 5 \mathrm{w} 3} / c^{*} d$

where $c$ is the estimated contribution of carbon in PLFAs to the total microphytobenthic carbon content $\left(\approx 0.035 \mathrm{gC}_{\mathrm{PLFA}} / \mathrm{gC}_{\text {microphytoben- }}\right.$ thos, see Middelburg et al., 2000), and $d$ is the estimated contribution of the used diatom PLFA biomarker (20:5w3) to the total microphytobenthos PLFA population ([PLFA] 20:5w3/(total [PLFA] minus bacterial [PLFA])), $\approx 0.11$. In order to compare $I_{\text {foraminifera }}$ with $I_{\text {bacteria }}$ and $I_{\text {diatom }}$ a dry density of $2.5 \mathrm{~g}$ sediment per $\mathrm{cm}^{3}$ was used and a sediment porosity of 0.75 was assumed.

\subsection{Statistics}

The Chi-square test for Independence (Pearson) was performed to analyze the difference in species-specific size-class distribution, calculated as percentages of the total population, between treatments and recovery stages. The calculated p-values were used to designate the similarity between the observed frequency distributions. When frequencies of the test sizes are similarly distributed the $\mathrm{p}$-value is 1 . Size classes were grouped in those cases where frequency occurred below $1 \%$.

The foraminiferal label uptake and carbon transfer were not statistically examined. Not all sample occasions have replicate measurements due to the high amount of small-sized specimens needed per sample to be able to measure the label uptake.

\subsection{Limitations of the experimental approach}

The experimental set-up has a limited number of sampling occasions. These sample occasions were first and foremost chosen to follow macrofaunal recovery and the relation between sediment biogeochemistry and macrofauna diversity and density (Rossi et al., 2009; Van Colen et al., 2012). In general, foraminifera respond faster than macrofauna (e.g., Brouwer et al., 2015). Hence, smaller time intervals between sample occasions would have been preferable to study foraminiferal dynamics. However, the chosen time intervals reflect the different stages of ecosystem restoration (Van Colen et al., 2012) and foraminiferal dynamics and diet shifts can be related to these stages.

There are no data available on the control patches of April and on glucose derived ${ }^{13} \mathrm{C}$ label incorporation in the recovering patches of April. The data collected in April were used to interpret the foraminiferal bicarbonate derived ${ }^{13} \mathrm{C}$ label incorporation and population dynamics succeeding hypoxia.

Table 1

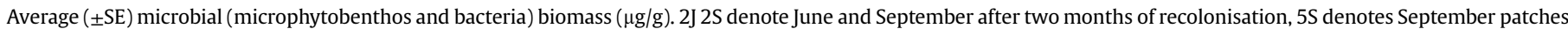
after five months of recolonisation, CJ and CS denote undisturbed control patches in June and September.

\begin{tabular}{|c|c|c|c|c|c|}
\hline & $2 \mathrm{~J}$ & $2 S$ & $5 S$ & CJ & CS \\
\hline Microphytobenthos & $150.5 \pm 9.6$ & $123.9 \pm 98.1$ & $105.4 \pm 3.5$ & $150.3 \pm 15.0$ & $94.5 \pm 7.0$ \\
\hline Bacteria & $76.2 \pm 5.6$ & $77.9 \pm 2.7$ & $71.7 \pm 1.6$ & $61.0 \pm 6.3$ & $56.6 \pm 2.8$ \\
\hline
\end{tabular}




\section{Results}

\subsection{Control patches}

Diatoms incorporated more bicarbonate and glucose derived ${ }^{13} \mathrm{C}$ label in the control patches of September than of June (Fig. 4a). Bacteria showed a similar pattern for the incorporation of bicarbonate derived ${ }^{13} \mathrm{C}$ label, whereas that for glucose was almost the same in both control patches (Fig. 4b). The ${ }^{13} \mathrm{C}$ enrichment of (autotrophic) diatoms in the bicarbonate-treated sediments was interpreted as direct uptake of the labeled bicarbonate and, similarly ${ }^{13} \mathrm{C}$-enrichment in (heterotrophic) bacteria in glucose-treated sediments as direct uptake of labeled glucose. However, diatoms in all patches treated with labeled glucose also revealed enrichment in ${ }^{13} \mathrm{C}$. This unintended enrichment was discussed by Rossi et al. (2009) and interpreted as a direct uptake of glucose by diatoms some of which are known for their capability to live heterotrophically in the absence of light. Bacteria were also enriched in ${ }^{13} \mathrm{C}$ in the patches treated with ${ }^{13} \mathrm{C}$ labeled bicarbonate. This enrichment is thought to reflect rapid bacterial consumption of alga-derived carbon enriched in ${ }^{13} \mathrm{C}$ label (Middelburg et al., 2000; Oakes et al., 2012). Both types of unintended, but unavoidable ${ }^{13} \mathrm{C}$ enrichments were considerably lower compared to the intended labeling (Fig. 4a, b).

The uptake of ${ }^{13} \mathrm{C}$-label by $A$. beccarii in the control patches indicated a decrease in glucose derived ${ }^{13} \mathrm{C}$-label and an increase in
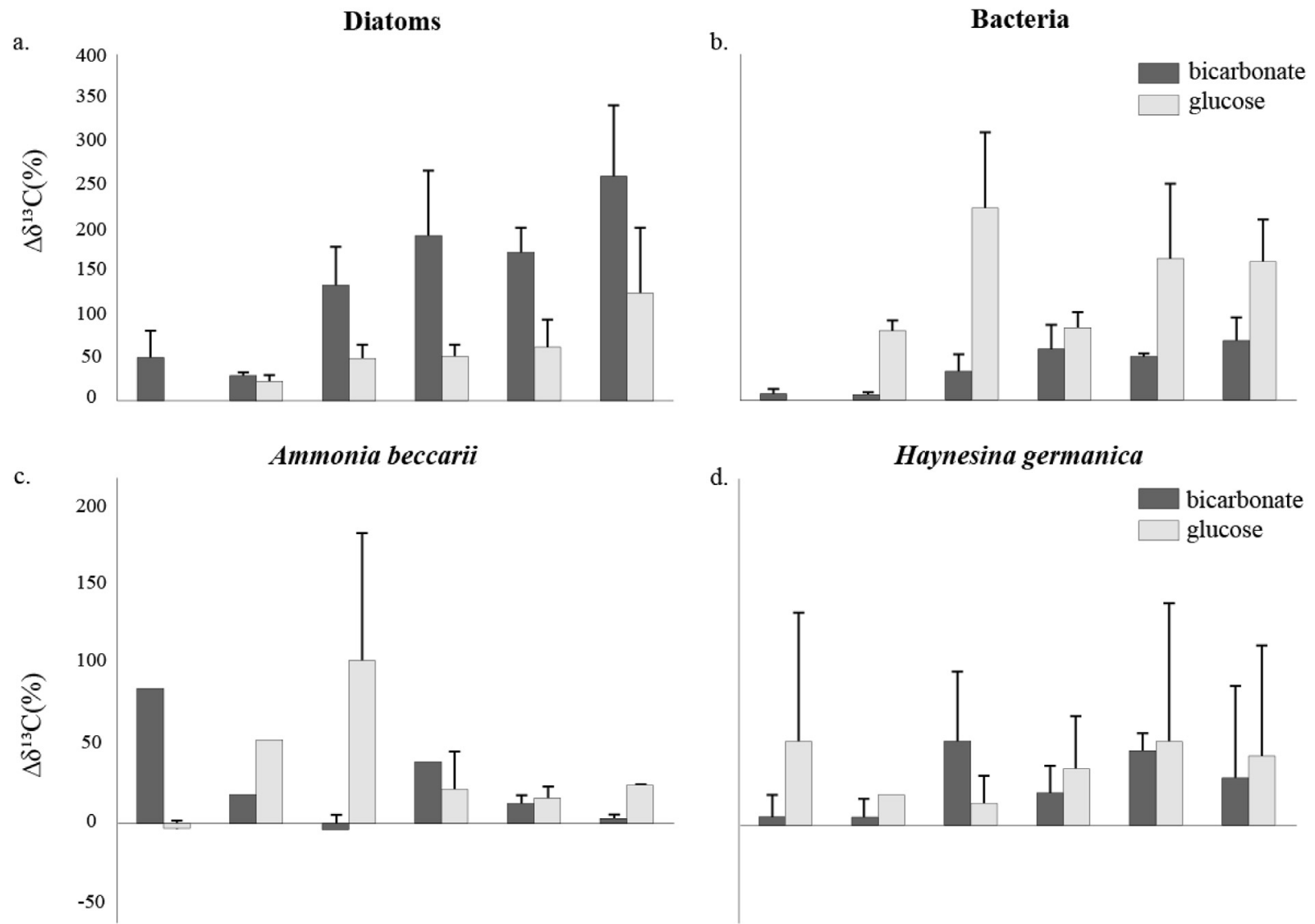

Ammonia beccarii $\Delta$ - ratio
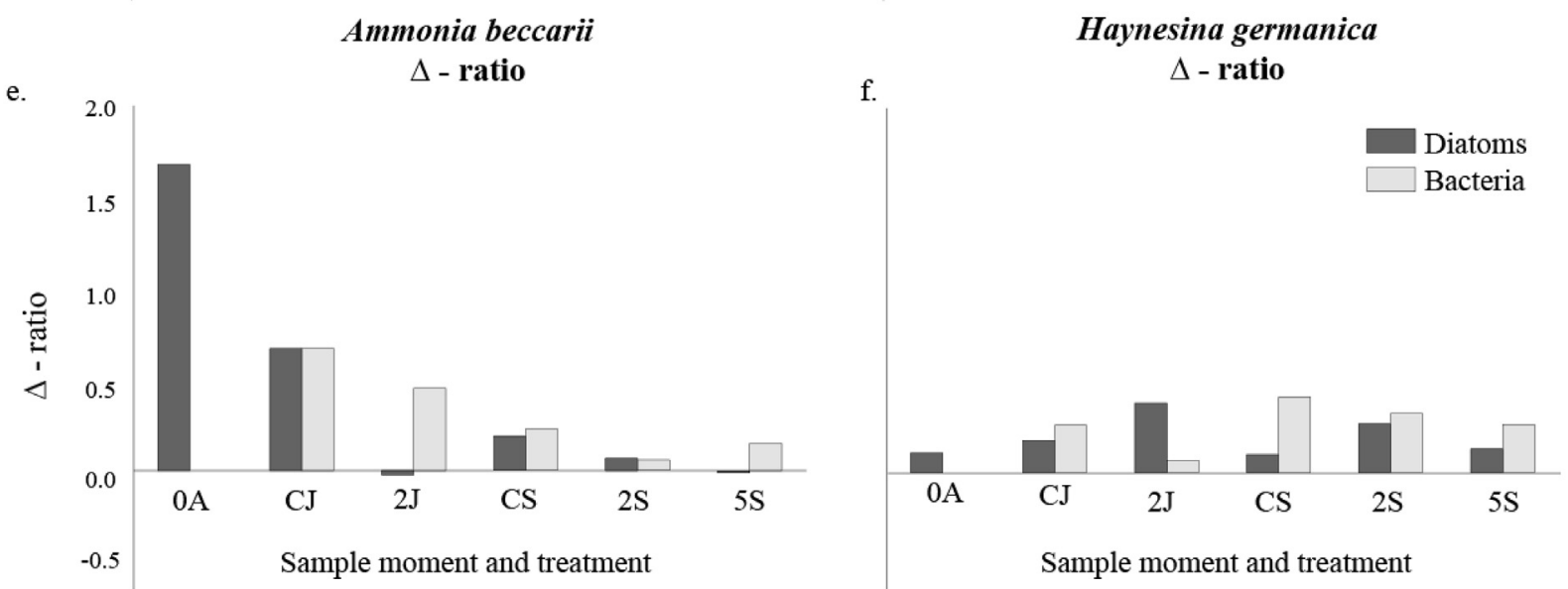

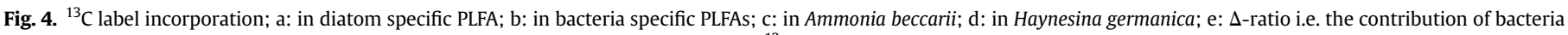
and diatoms to the diet of Ammonia beccarii; f: $\Delta$-ratio in Haynesina germanica. All $\Delta \delta^{13} \mathrm{C}$ values are shown plus one standard deviation. 
bicarbonate derived ${ }^{13} \mathrm{C}$-label from June to September (Fig. 4c). $\mathrm{H}$. germanica incorporated more bicarbonate- and glucose-derived ${ }^{13} \mathrm{C}$-label in September than in June (Fig. 4d). The calculated $\Delta$-ratios of $A$. beccarii and $H$. germanica in the control patches, based on label incorporation in foraminifers and microbes, indicated for A. beccarii a very similar food-uptake pattern in June and September (CJ vs. CS, Fig. 4e). In the control patches of September the relative contribution of bacteria to the diet of $H$. germanica had increased compared to June (Fig. 4f). The density of $A$. beccarii in the control patches of June and September was comparable, whereas the density of $H$. germanica in these patches decreased from June to September (Table 2). During both sample occasions, the size distribution in the control patches was relatively similar for both species (CJ vs. CS, Figs. 5a-b and $6 \mathrm{~b}$ and $7 \mathrm{~b}$ ).

\subsection{Timing of disturbance - (2J vs. 2S)}

The bacteria incorporated more glucose derived ${ }^{13} \mathrm{C}$-label in the patches that had recovered for two months after the winter- and spring hypoxia compared to the concurrent control patches (Fig. 4b). Analogously, for diatoms a distinct difference in the bicarbonate derived ${ }^{13} \mathrm{C}$-label was observed between the hypoxiatreated and the control patches of June (Fig. 4a). The timing of disturbance seemed to have differentially affected the diet of $H$. germanica and $A$. beccarii (Fig. 4c, d, e, f). The $\Delta$-ratio, for instance, suggested that $A$. beccarii fed predominantly on bacteria and $H$. germanica on diatoms, two months after the winter hypoxia, whereas the diet of both species was comparable two months after the spring hypoxia (Fig. 4e and f). In particular, both species consumed slightly more bacteria than diatoms two months after the spring hypoxia, though $A$. beccarii had a very low incorporation of label, implying reduced food uptake. In short, diets of both species differed more from the controls after the winter than after the spring hypoxia (Fig. 4a, b).

The abundance of $A$. beccarii seemed to be slightly higher in the disturbed patches compared to the controls (Table 2). Moreover, the distribution of test sizes of A. beccarii, displayed in Figs. 5a and 6 , revealed that the disturbed patches contained a relatively high proportion of large specimens compared to the control; this difference is, as for the abundance, most pronounced after the winter hypoxia. This latter observation is confirmed by the Chi-square test; the p-value of $2 \mathrm{~J}$ vs. CJ (2.24E-02) is smaller than the p-value of $2 \mathrm{~S}$ vs CS (4.96E-02) which in turn smaller than CJ vs. CS (7.80E-02, see Appendix). In contrast, the specimens of $H$. germanica were on average smaller (Figs. 5b and 7) and less numerous (Table 2) in the disturbed patches of June compared to those in the control and the disturbed patches of September. These latter patches contained the highest proportion of large individuals (Figs. 5b and 7).

\subsection{Recovery development - (0A vs. $2 J$ vs. $5 S)$}

In April, A. beccarii had a peak uptake of bicarbonate-derived label in the disturbed patches (Fig. 4c); the bicarbonate-derived $\Delta \delta^{13} \mathrm{C}$ value of $A$. beccarii exceeded the bicarbonate-derived $\Delta \delta^{13} \mathrm{C}$ of the diatoms (Fig. 4a). Two months later, A. beccarii fed predominantly on bacteria (Fig. 4e). In September, A. beccarii revealed a low uptake of both glucose and bicarbonate-derived ${ }^{13} \mathrm{C}$-label in all patches (Fig. 4c, e), despite high concurrent levels of label incorporation in both diatoms and bacteria (Fig. 4a, b). Contrastingly, after the winter hypoxia, $H$. germanica fed on bacteria in April, and predominantly on diatoms in June (Fig. 4f). Interestingly, the foraminiferal incorporation of label in the control patches did not indicate major diet shifts.

A. beccarii had, in the recovery patches after winter hypoxia, a relatively high proportion of large test sizes in June compared to April and September, whereas the specimens of $H$. germanica increased in size during ecosystem recovery (Figs. 5a, 6 and 5b, 7). Despite the observed fluctuation in test-size distribution of A. beccarii, its abundance was comparable among the sample occasions following the winter hypoxia (Table 2). The high density of H. germanica in April and its strong decrease afterwards (Table 2) is striking. The distribution of the test size of both species in the control patches of June and September differed less than those between the hypoxia-treated patches in June and September (Appendix).

\subsection{Recovery stages - (2S vs. $5 S)$}

Although label uptake by bacteria and diatoms was high in all patches sampled in September (Fig. 4a, b), A. beccarii showed a low uptake of label suggesting lower feeding activity (Fig. 4c, e). In contrast, $H$. germanica showed a more pronounced uptake of label in at least a part of the replicate samples (i.e., standard deviations were high) in all September patches (Fig. 4d, f). On average in this time of year, bacteria seemed to contribute slightly more to the diet of $\mathrm{H}$. germanica than diatoms, although a relatively high incorporation of likely algal-derived ${ }^{13} \mathrm{C}$ label was found in the patches treated with a spring hypoxia.

The Chi-square test indicated that the test-size distribution of A. beccarii differed among the September samples; the pairwise comparison of $2 S$ versus CS gave a p-value of 0.05 and that of $5 S$ vs. Cs and 2S vs. 5S a p-value of respectively 0.19 and 0.17 (see Appendix). Although the dissimilarity was relatively small, the species from sediments that suffered spring hypoxia were proportionately larger than those that suffered winter hypoxia, and the control samples contained a higher proportion of smaller specimens than the hypoxia-treated sediments. September populations of $H$. germanica displayed relatively large specimens in the hypoxiadisturbed patches and a high similarity in the size distribution among the patches treated with winter or spring hypoxia (Fig. $7 \mathrm{~d}$, see Appendix).

\subsection{Carbon transfer from microbes to foraminifera}

A. beccarii was estimated to have consumed on average $3.0 \%$ of the total bacterial biomass and $H$. germanica $2.9 \%$ (Table 3 ). The consumption of diatoms by $A$. beccarii and $H$. germanica was estimated at respectively $0.6 \%$ and $0.8 \%$ of the total diatom biomass (Table 3). Interestingly, despite the high similarity between the mean bacterial and diatom uptake of $A$. beccarii and $H$. germanica, large differences were found among treatments and sample moments within and between populations of both foraminiferal

Table 2

Mean abundance $( \pm 1 \mathrm{SE})$ of foraminifera in the top $1 \mathrm{~cm}$ of the sediment surface (no $\times 3.14 \mathrm{~cm}^{-3}$ ).

\begin{tabular}{|c|c|c|c|c|c|c|}
\hline & $0 A$ & $2 \mathrm{~J}$ & $2 S$ & $5 S$ & $\mathrm{CJ}$ & CS \\
\hline Haynesina germanica & $394.3 \pm 103.8$ & $116.6 \pm 11.1$ & $191.9 \pm 30.7$ & $155.0 \pm 16.8$ & $155.5 \pm 33.2$ & $100.9 \pm 19.3$ \\
\hline Ammonia beccarii & $39.8 \pm 9.0$ & $35.4 \pm 5.0$ & $25.8 \pm 7.6$ & $36.1 \pm 11.5$ & $19.8 \pm 3.5$ & $22.0 \pm 5.0$ \\
\hline Elphidium excavatum & $47.5 \pm 2.6$ & $19.0 \pm 3.2$ & $2.0 \pm 1.4$ & $0.0 \pm 0.0$ & $24.7 \pm 6.5$ & $8.5 \pm 3.2$ \\
\hline
\end{tabular}




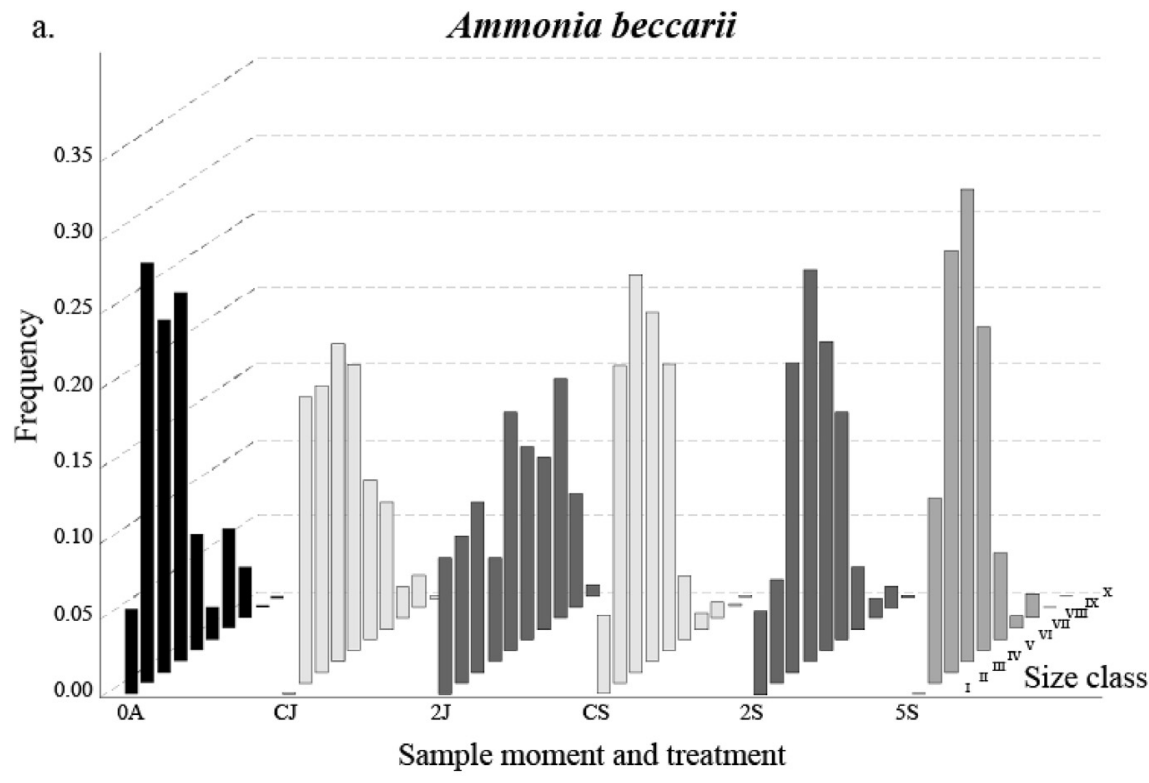

b. Haynesina germanica

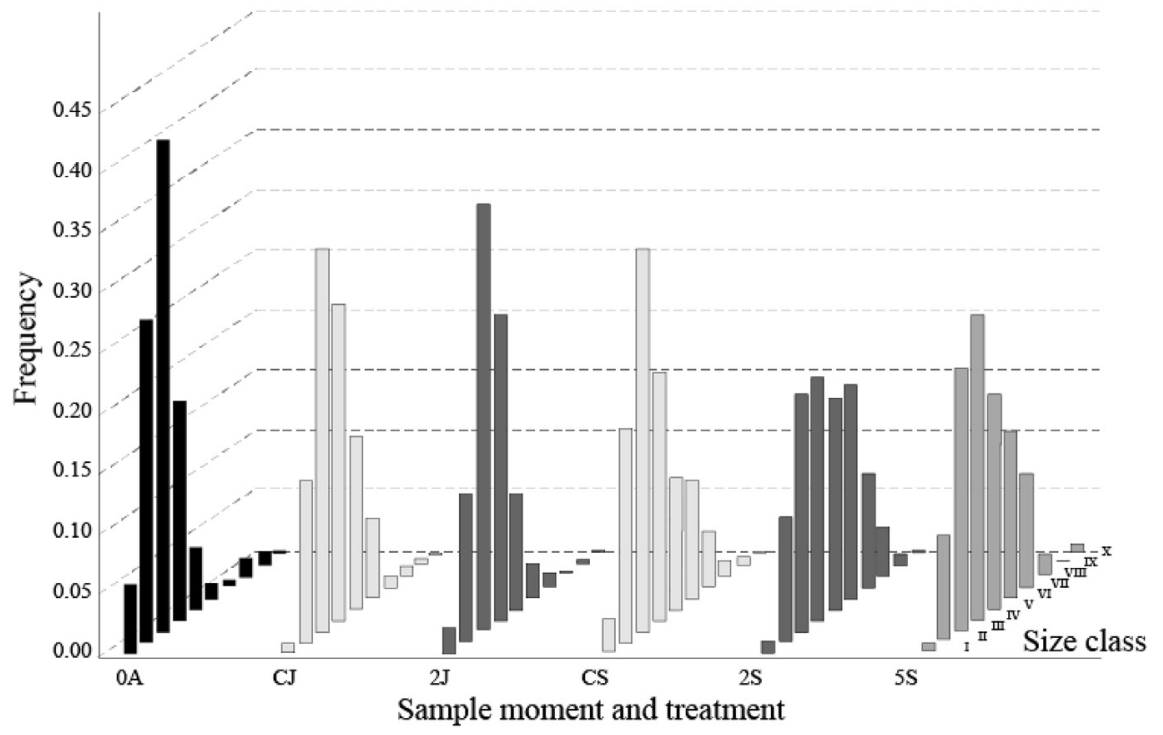

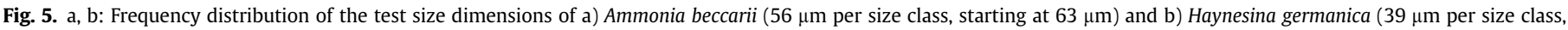
starting at $63 \mu \mathrm{m})$.

species. The estimated carbon transfer from bacteria to A. beccarii was much higher in June compared to September (Table 3). There was a distinct deviation between its contribution to the transfer of the diatom- and bacterial-derived carbon among the recovery and disturbed patches of June; no significant amount of diatom-derived carbon seemed to have been used up by this species in the recovery patches. H. germanica predominantly contributed to the transfer of bacterial-derived carbon, except for the control patches of June where it also took up a substantial amount of the diatom-derived carbon (Table 3).

\section{Discussion}

Label incorporation and test-size distributions of $A$. beccarii and $H$. germanica differed among recovery stages and between hypoxiaaffected and unaffected (control) sediments. In the following paragraphs foraminiferal diet shifts and population dynamics will be interpreted and set in the context of ecosystem recovery and timing of hypoxic disturbance.

\subsection{Foraminiferal diet shifts and population dynamics}

Similar to the previously mentioned unintended labeling of diatoms (Rossi et al., 2009) direct uptake of ${ }^{13} \mathrm{C}$-labeled glucose by foraminifera may have occurred in our experiments since at least some foraminifera are capable to directly use dissolved organic matter. In an in situ experiment with large dendriform agglutinated foraminifera from Antarctica, DeLaca et al. (1981) could demonstrate the uptake of glucose. The two species that have been shown to utilize dissolved organic carbon (DOC) live in an exceptionally oligotrophic environment in shallow waters below sea ice in which primary productivity is very low and restricted to one or two months a year (DeLaca et al., 1981). The capability of using DOC may be a specialized adaption to survive the long yearly periods lacking 


\section{Ammonia beccarii}

a.

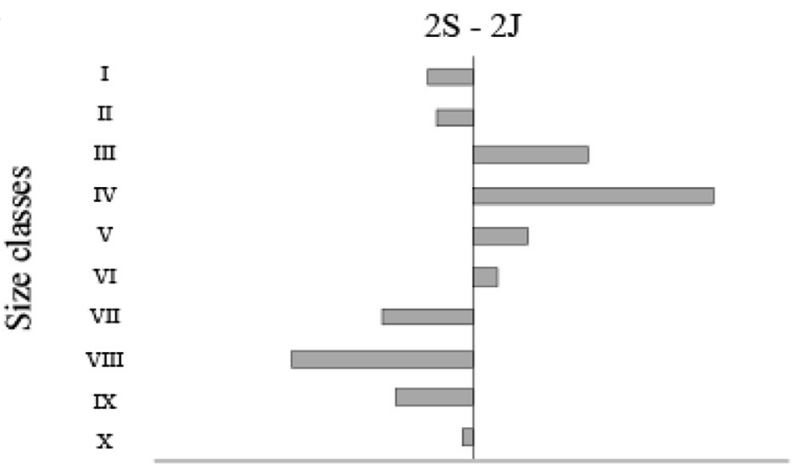

c.

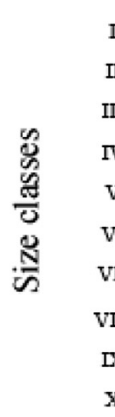

e.

$$
\begin{aligned}
& \text { I } \\
& \text { 总 }
\end{aligned}
$$

g.

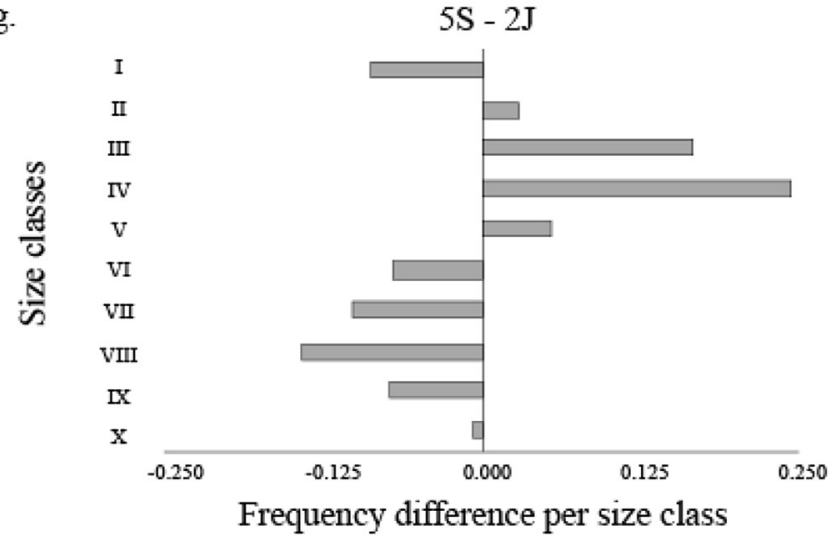

b.

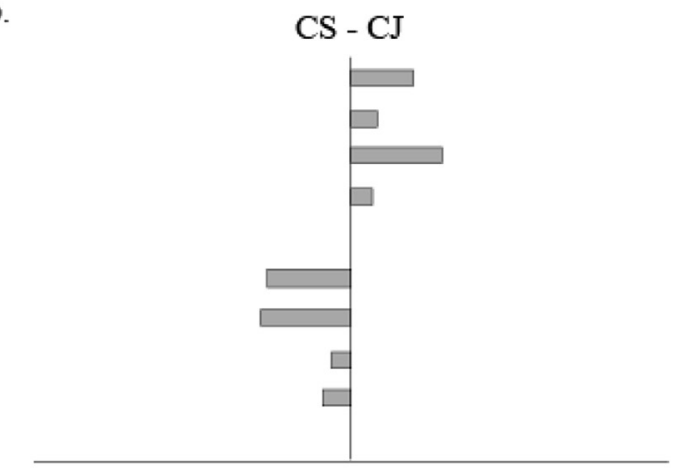

d.

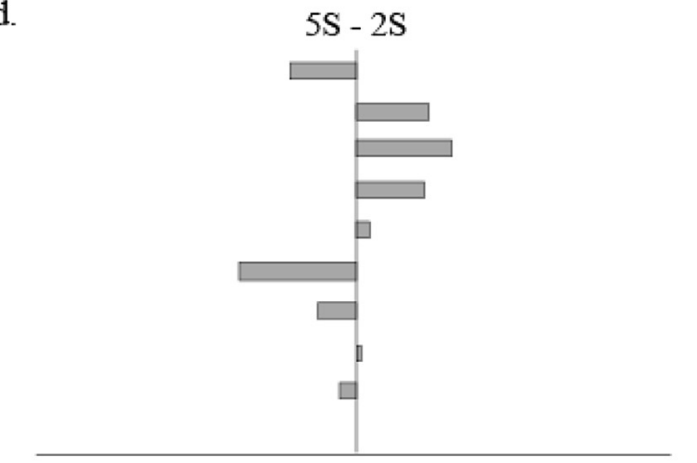

f.

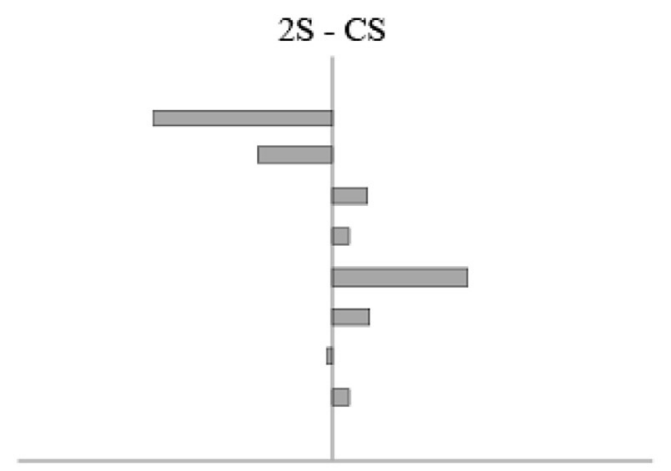

h.

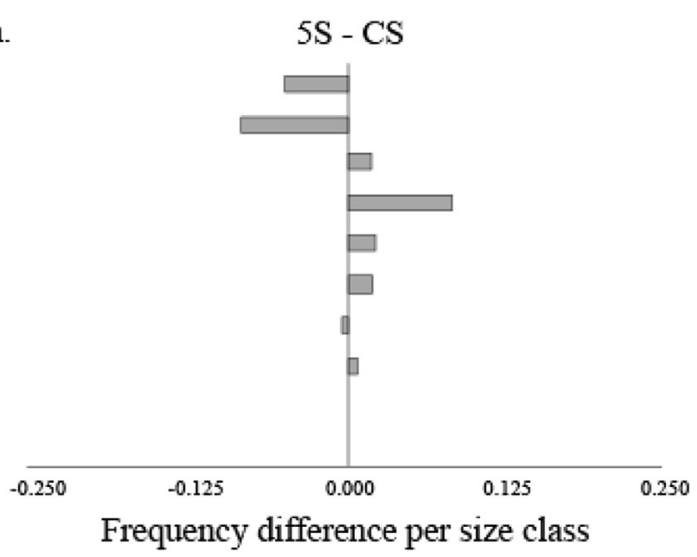

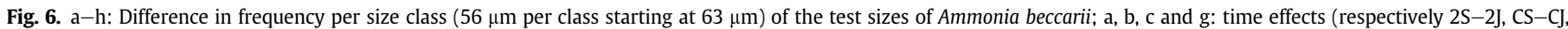
$2 \mathrm{~J}-\mathrm{OA}$, an $\mathrm{d} 5 \mathrm{~S}-2 \mathrm{~S}$ ); d, f, g and h:hypoxia treatment and timing/duration of system recovery effects (respectively 2J-CJ, 2S-CS, 5S-2J and 5S-CS).

production of particulate organic matter. Nonetheless, direct uptake of ${ }^{13} \mathrm{C}$-labeled glucose by meiofauna has been discussed to occur on the nearby situated tidal flat of the Molenplaat (Van
Oevelen et al., 2006). We cannot rule out some direct foraminiferal uptake of labeled glucose in our experiments - potentially leading to overestimated importance of bacteria as food source. 


\section{Haynesina germanica}

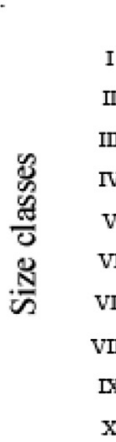

c.

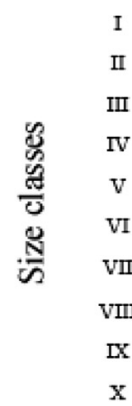

e.

范

g.

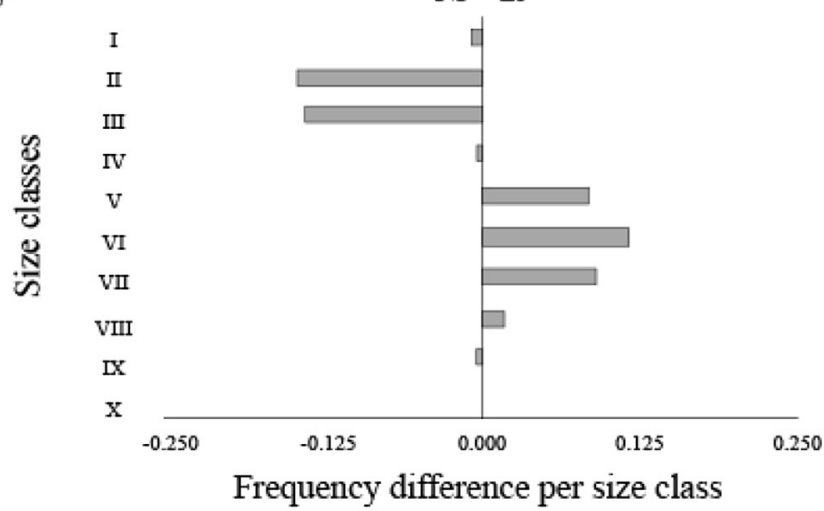

b.

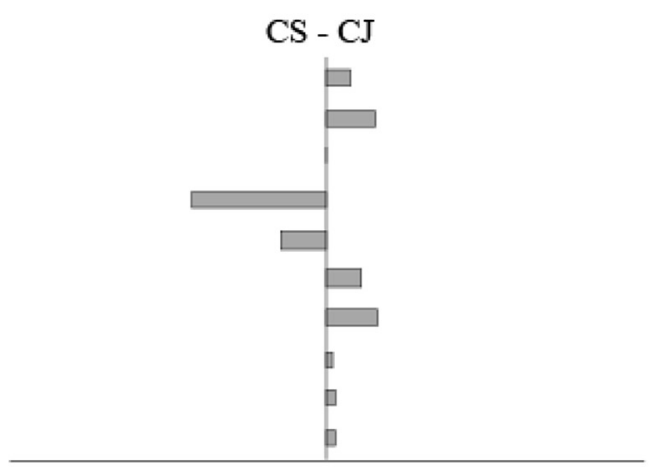

d.

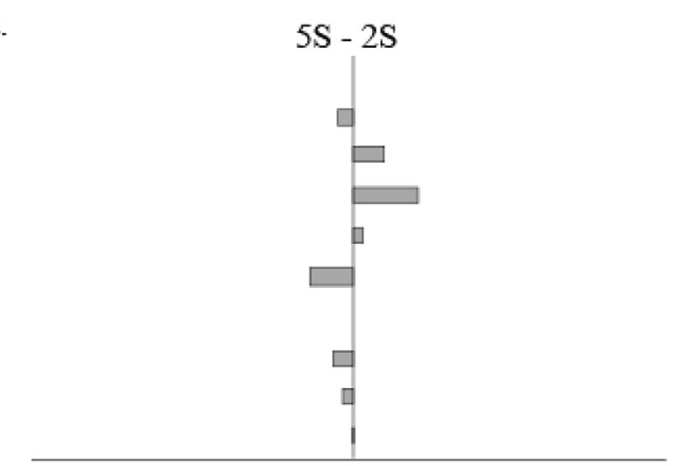

f.

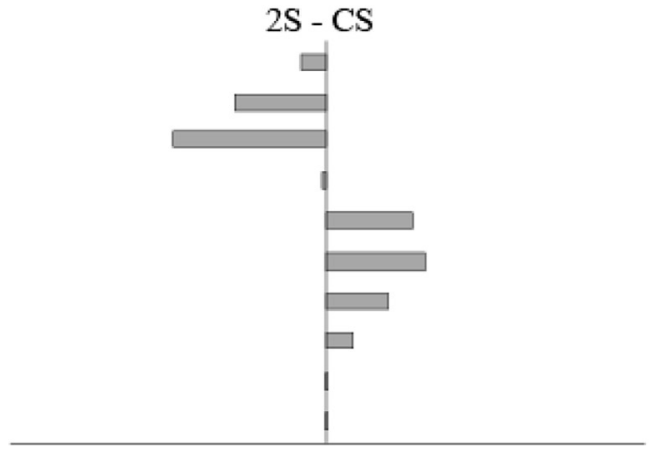

h.

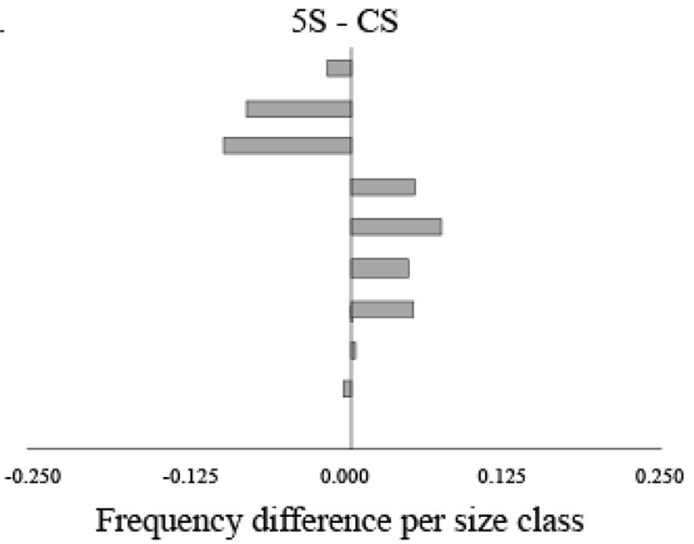

Fig. 7. a-h: Difference in frequency per size class ( $39 \mu \mathrm{m}$ per class starting at $63 \mu \mathrm{m}$ ) of the test sizes of Haynesina germanica; a, b, c and g: time effects (respectively $2 \mathrm{~S}-2 \mathrm{~J}$, CS-CJ, 2J-OA, an d $5 S-2 S$ ); d, f, g and h: hypoxia treatment and timing/duration of system recovery effects (respectively 2J-CJ, 2S-CS, 5S-2J and 5S-CS).

However, our variable label uptake results (Fig. 4) do not suggest a strong influence of direct glucose consumption. Sampling the sediment $96 \mathrm{~h}$ after the addition of labeled glucose may have limited misinterpretation through direct label uptake; the turnover time of glucose in meiofauna is in general much shorter (hours) than that of bacteria (days) (Van Oevelen et al., 2006). The observed 
Table 3

Carbon transfer in \% of diatom-specific PLFA and bacterial-specific PLFA's to Ammonia beccarii and Haynesina germanica.

\begin{tabular}{|c|c|c|c|c|}
\hline Sample moment * treatment & Ammonia beccarii/diatoms & Ammonia beccarii/bacteria & Haynesina germanica/diatoms & Haynesina germanica/bacteria \\
\hline $2 \mathrm{~J}$ & 3.13 & 5.01 & 1.89 & 3.20 \\
\hline $2 S$ & -0.20 & 7.43 & 0.84 & 0.39 \\
\hline $5 S$ & 0.13 & 0.84 & 0.15 & 3.14 \\
\hline CJ & 0.05 & 0.46 & 0.69 & 4.65 \\
\hline CS & 0.01 & 1.16 & 0.22 & 3.33 \\
\hline Average & 0.63 & 2.98 & 0.76 & 2.94 \\
\hline
\end{tabular}

relatively high dissimilarity in label uptake by foraminifera among replicate samples was previously noticed by Moodley et al. (2002); it is presumably attributable to dissimilarities in individual feeding activity among the specimens. Given these uncertainties, particularly the peaks in label uptake provide insight in foraminiferal feeding activities.

The $\Delta$-ratio revealed foraminiferal diet shifts and the foraminiferal abundance and distribution of the maximum test-size dimension indicated shifts in the population structure of $A$. beccarii and $H$. germanica, especially during ecosystem recovery. In April, a high enrichment in ${ }^{13} \mathrm{C}$ was measured in $A$. beccarii suggesting that this species profited from the development of a dense mat of benthic diatoms during the first period of ecosystem recovery (Fig. 4, Montserrat et al., 2008; Van Colen et al., 2012). The $\Delta$ ratio was above $100 \%$; suggesting selective feeding by $A$. beccarii on autotrophs with an above average enrichment in ${ }^{13} \mathrm{C}$ within the group of algae (i.e. with a higher growth rate). Comparison of label incorporation in the dinoflagellate PLFA 22:6w3 with that in diatom PLFA 20:5w3 could not corroborate this hypothesis. The clear uptake of algal carbon by $A$. beccarii is in agreements with previous reports (e.g. Moodley et al., 2000; Pascal et al., 2008). Pascal et al. (2008) suggested that Ammonia tepida (likely the same species as $A$. beccarii in this paper) was mainly dependent on algal resources. As their experiment was conducted in March (2006), these results are in agreement with our springtime results. In our experiment, the high proportion of large test sizes in the recovery patches of June may reflect individual growth of $A$. beccarii in response to this amply available food source, leaving relatively low numbers of intermediately-sized individuals. Concurrently, high numbers of small specimens may represent stable reproduction rates, similar to those that sustained the relatively high numbers of smaller foraminifera in the control samples (Figs. 5a and 6). By June, $A$. beccarii had shifted from grazing on diatoms towards consumption of bacteria (Fig. 4). Ingestion of bacteria by A. beccarii has been reported previously by e.g. Chandler (1989); Langezaal et al. (2005); Pascal et al. (2008); Mojtahid et al. (2011). Muller and Lee (1969) discussed that the consumption of bacteria may stimulate foraminiferal fecundity and reproduction. The observed diet shift of A. beccarii towards bacteria during reproduction could corroborate a possible importance of bacteria for reproduction. In the winter hypoxia-disturbed patches of September (5S, Fig. 5a), the distribution of the test-size dimension indicated a relatively high proportion as well as absolute abundance of medium-sized specimens of $A$. beccarii. The low ${ }^{13} \mathrm{C}$ enrichment of these September foraminifera may indicate that $A$. beccarii became relatively inactive.

Stress, induced by the hypoxic treatment possibly triggered reproduction of $H$. germanica. Two weeks after the hypoxic treatment, prior to intense algal mat formation, high numbers of relatively small sizes specimens were found in comparison to subsequent sample moments (Figs. 5b and 7c). Towards June, after two months of ecosystem recovery, the density of $H$. germanica had declined by approximately 70\% (Table 2, Brouwer et al., 2015). The distribution of the test-size dimensions of this species revealed slightly larger test sizes in the recovery plots of June compared to
April, although they were small in contrast to the specimens in the control plots. The strong decline in abundance may be related to for instance high mortality rates, downwards migration induced by increased predation pressure by nematodes and macrofauna (as previously reported by Buzas, 1978) that abundantly colonized the disturbed patches after re-establishment of oxygen pore-water concentrations (Van Colen et al., 2012). Despite the high fluctuations in abundance, the enrichment in ${ }^{13} \mathrm{C}$ measured in $H$. germanica indicated smaller fluctuations in food uptake and diets shifts compared to $A$. beccarii. Although the amply available diatoms (Table 1, Rossi et al., 2009) contributed more to the diet of $H$. germanica in the disturbed patches of June, bacteria seemed to dominate the diet of this species in all other patches. In contrast to A. beccarii, this species did not seem to profit from the high availability of benthic algae during the first months of ecosystem recovery in terms of reproduction or growth as reflected by the testsize distribution. The absence of a clear response of $H$. germanica to high algal densities has previously been reported (Moodley et al., 2000). Feeding on bacteria may be preferential for $H$. germanica; however - although diatom biomasses were high in April perchance (the larger) A. beccarii was better enabled to respond fast to the diatom bloom arising (Montserrat et al., 2008; Van Colen et al., 2012) in the period directly after the winter-hypoxia had ended. Moodley et al. (2000) suggested that differential responses between $A$. beccarii and $H$. germanica might indicate resource partitioning. The observed opposite shift in diet between $A$. beccarii and $H$. germanica is in line with this hypothesis, but it would require that preferred food availability was low enough to be limiting population sizes. Given the wealth of high quality food due to a lack of grazers in the early recovery phase after the hypoxia (Montserrat et al., 2008; Van Colen et al., 2012) this does not seem to be a very likely scenario.

\subsection{Impact of ecosystem functioning on foraminifera}

$H$. germanica responded differently - often even inversely compared to $A$. beccarii - to the hypoxic treatment with respect to abundance, test-size distribution and food-consumption patterns. Competition between these species as well as a differential impact of ecosystem properties presumably provoked these opposite responses. As suggested by Duijnstee et al. (2005) some foraminiferal taxa change their life-history strategy during times of stress and disturbance, whereas other may not. This may produce differential population-level responses to the same set of changing environmental conditions.

The hypoxic treatments and the succeeding recovery impacted various aspects of the estuarine ecosystem. The exposure to hypoxic conditions resulted in a mass mortality of all macrobenthic species (Van Colen et al., 2008, 2012; Rossi et al., 2009). The absence of macrofaunal grazers during the first period of ecosystem recovery facilitated the development of a benthic algal mat exploited by especially $A$. beccarii. During ecosystem recovery, macrofaunal recolonization developed via stages that differed in species composition, total abundance and biomass of the 
assemblage. The first stage (April to June) was characterized by an abundance increase of predominantly small-sized macrofaunal species and in the sequel stage (June to September) these numerous small-sized specimens were replaced by fewer, but larger individuals (Rossi et al., 2009).

In contrast to foraminifera, nematode abundance sharply declined due to the hypoxic perturbation (Van Colen et al., 2009, 2012). As suggested by Moodley et al. (1997), nematodes and foraminifera may compete for food. Therefore, the hypoxia-induced lowering of the nematode abundance may have been beneficial to the stress tolerant foraminiferal species $A$. beccarii. Succeeding the hypoxia-induced decline in abundance, nematode numbers recovered fast to control levels (within 56 days) and peaked three months after the onset of recovery (Van Colen et al., 2009). The high increase in nematode abundance and the concurrent arrival of numerous small-sized macrofaunal specimens during the first period of recovery, may have contributed to the sharp decline observed in densities of $H$. germanica (Table 2, Brouwer et al., 2015).

\subsection{Seasonal effect of hypoxia}

As mentioned earlier, the foraminiferal population structure and food consumption patterns of both foraminiferal species indicated that the populations in the patches that recovered for 2 months after the spring hypoxia (2S) were more similar to those left to recover for 5 months (5S, i.e. those sampled in September) than to those that recovered for 2 months after the winter hypoxia and sampled in June (2J). As reported for macrofaunal abundance, biomass, and species diversity (Rossi et al., 2009) our results suggest that, for the foraminiferal diet and population structure, timing of sampling after disturbance (i.e. when in the seasonal cycle) might be of greater importance than being allowed to recover for a period of two or five months. Besides biotic interactions as food web dynamics (e.g. algal spring bloom, a dissimilar response of macrofauna to the winter- and spring-hypoxia due to for instance larval availability, predation pressure and competition for food), also seasonal dynamics in abiotic ecosystem properties may have influenced the foraminifera.

Temperature has been reported to impact foraminiferal growth, feeding and reproduction (Bradshaw, 1957, Pascal et al., 2008a and b). The optimum temperature for growth and reproduction of Ammonia is $25-30{ }^{\circ} \mathrm{C}$ and the optimum of bacterial uptake by Ammonia is recorded at $30^{\circ} \mathrm{C}$ (Bradshaw, 1957). The generally low temperature during winter (below $10{ }^{\circ} \mathrm{C}$ Ammonia fails to grow, Bradshaw, 1957, and below $5{ }^{\circ} \mathrm{C}$ bacteria uptake by Ammonia stops, Pascal et al., 2008) has been suggested to limit growth and reproduction, while high summer temperatures may provoke foraminiferal mortality (Pascal et al., 2008a). It is likely that growth and reproduction of other foraminiferal species, and thereby their resilience and response to disturbance, are equally affected by temperature.

\subsection{Carbon flow}

Foraminiferal grazing on bacteria was estimated at 3.0\% for $A$. beccarii and $2.9 \%$ for $H$. germanica. We estimated that on average $0.6 \%$ of the diatom biomass was eaten by $A$. beccarii and $0.8 \%$ by $H$. germanica (Table 3). Despite the similarity in the mean contribution of $A$. beccarii and $H$. germanica to the microbial transfer, grazing on microbes differed per sample moment and treatment. The contribution of foraminifers to the transfer of carbon rests on several properties as, for instance, the microbial biomass and the percentage of microbes enriched in ${ }^{13} \mathrm{C}$, the total foraminiferal biomass, interspecific competition for food among foraminifera and other faunal species, etc. The combined effect of these separate properties determines the estimated importance of foraminifera in the transfer of microbial carbon. These properties fluctuate not only seasonally in the same patches (as in our experiment), but they are also highly variable among environmental settings. Moodley et al. (2000) estimated that Ammonia ingested $1-7 \%$ of the green algae that were added in their study within 3-53 h. If the amount of available algal material per foraminifer in their study does not exceed the available algal biomass per foraminifer in our experiment, and if there is no difference in food preference between Moodley et al.'s green algae and our microphytobenthos then this might imply that the role of foraminifera in using up microphytobenthos resources was somewhat greater in our experiment than in that of Moodley et al. What further complicates this comparison, though, is that Moodley et al. (2000) added pre-cultured, already labeled, freeze-dried green algae whereas we labeled the ambient environment of the community of benthic algae in situ. Moreover, selective feeding of Ammonia among the benthic algal community was indicated by $\Delta$-ratio above $100 \%$.

Oakes et al. (2012) investigated microphytobenthos-derived carbon transfer in Australian subtropical subtidal sandy sediments by adding $\mathrm{NaH}^{13} \mathrm{CO}_{3}$ to label the DIC pool in the water column. Sediments were sampled 6 times over a period of 3-33 days after the addition of label. At their study site, foraminifera dominated the meiobenthic community and macrofaunal species were scarce. Three species dominated the foraminiferal community, Cellanthus craticulatis, A. beccarii (potentially a different, yet closely related species to ours) and Elphidium advenum. Especially C. craticulatis, the biomass of which peaked at $3.8 \%$ of the total organic carbon biomass, accounted for up to $31 \%$ of the ${ }^{13} \mathrm{C}$ within the sediment. A. beccarii and Elphidium advenum represented respectively $0.2 \%$ and $0.1 \%$ of the total organic carbon biomass; their contribution to the ${ }^{13} \mathrm{C}$ in the sediment corresponded to their contribution to the organic carbon biomass. The high dissimilarity among the contribution of the benthic foraminiferal species to the transfer of carbon (relative to their biomass) was suggested to be attributable to functional chloroplasts in C. craticulatis and the absence of these chloroplasts in the other foraminifera. The relative role of $A$. beccarii and Elphidium advenum in the consumption of the total microphytobenthos standing stock roughly corresponded to our estimates of the contribution of $A$. beccarii (consumed on average $0.6 \%$ of the available diatoms) and $H$. germanica (consumed on average $0.8 \%$ of the available diatoms) to the diatom derived carbon transfer by foraminifera.

\subsection{Implications for biomonitoring}

The aim of the experiment was to gain more insight into the development of foraminifera in particular in terms of assemblage composition, population dynamics and diets shifts during ecosystem recovery succeeding hypoxia. The temporal dynamics in abundance and the development of the test-size structure of foraminiferal populations provides insight in their life-history. It reflects the windows of opportunity for growth and reproduction, driven by changes in the dynamics of food sources, competition, predation and seasonal timing in the year. Exploring tracer inferred foraminiferal diets shifts helped to fill in the importance of food availability as driving force behind the observed foraminiferal population dynamics. Enhanced insight in the relative importance of biotic and abiotic environmental factors such as oxygen and food availability, food-web interaction, and macrofaunal recolonization, will help to improve the accuracy of foraminifera as ecological indicators for biomonitoring ecosystem development after coastal hypoxia.

Our results reveal that the impact of ecosystem recovery following hypoxia was reflected in the abundances and the test-size 
structure of individual foraminiferal populations. Specialization among species was observed; especially food availability, i.e. biomasses of microphytobenthos and heterotrophic bacteria, played an important role in the development of the foraminiferal populations in the first months after disturbance. With progressive ecosystem recovery and macrofaunal recolonization, the interactions within the estuarine community increased and became more and more complex. This higher complexity, with an increase of direct and indirect interactions within and among trophic levels, complicates a straightforward unraveling of the explicit contribution of separate environmental factors on foraminiferal dynamics.

The presented study is innovative as it combines the advantages of an experimental set-up - enabling the comparison among hypoxia-exposed and control sediments - with a field setting taking into account all direct and indirect interactions. This approach provide the opportunity to relate the observed foraminiferal dynamics to fluctuations in the availability of microphytobenthos and bacteria. Our results show that besides assemblage information, size distributions are also a valuable tool for ecosystem monitoring efforts. Nonetheless, in order to deduce more precisely the impact of separate factors on the foraminiferal development during prolonged ecosystem recovery, this study should be supplemented by controlled laboratory studies investigating these interactions in a more simplistic manner. By setting the presented findings in the context of controlled laboratory studies, a further improvement of our understanding of the relative importance of biotic and abiotic environmental factors on foraminiferal dynamics during ecosystem recovery can be gained; this will further improve the role that foraminifera can play as bioindicators of ecosystem health.al species.

\section{Conclusion}

With regard to their diet and population dynamics, the dominant foraminiferal species $A$. beccarii and $H$. germanica responded differentially and generally inversely to progressive stages of ecosystem recovery succeeding hypoxia. The $\Delta$-ratio values strongly suggest that the development of a dense mat of benthic algae during the first month of ecosystem recovery after the winter hypoxia was profitable to $A$. beccarii. This food pulse may have stimulated reproduction as well as growth as indicated by two distinctly visible cohorts in the test-size distribution after two months: a relative high proportion of small and large sized specimens in the recovery patches of June compared to controls. Enhanced reproduction itself was strongly linked to the subsequent dietary shift to bacteria. The distribution of the test dimensions of $H$. germanica indicated that this species had less fluctuation in population structure during ecosystem recovery but possibly reproduced in response to the induced winter hypoxia. Also its inferred dietary composition fluctuated markedly less than that of A. beccarii. In general, bacteria seemed to contribute more to the diet of $H$. germanica than diatoms. The timing of sampling after disturbance seemed to be a more important factor to the foraminiferal dietary and population structure patterns than whether the duration of recovery from the hypoxia had been 2 or 5 months.

\section{Acknowledgment}

Two anonymous reviewers are acknowledged for their critical comments that help improve an earlier version of this manuscript. This publication was partially funded by the Darwin Center for Biogeosciences. Financial support to M.W. is acknowledged from the U.K.'s Natural Environment Research Council (fellowship \#NE/ J018856/1).

\section{Appendix}

Table A1

Chi-Square test-derived p-values comparing pairwise test size distributions of Ammonia beccarii and Haynesina germanica among treatments and duration of recovery.

\begin{tabular}{|c|c|c|c|c|c|c|}
\hline \multirow[t]{2}{*}{ Sample moment * treatment } & \multicolumn{3}{|c|}{ Ammonia beccarii } & \multicolumn{3}{|c|}{ Haynesina germanica } \\
\hline & Chi 2 & df & $\mathrm{P}$ & Chi 2 & $\mathrm{df}$ & $\mathrm{P}$ \\
\hline OA vs $2 \mathrm{~J}$ & 53.6 & 7 & 2.83E-09 & 34.0 & 6 & $6.81 \mathrm{E}-06$ \\
\hline $2 \mathrm{~J}$ vs $5 \mathrm{~S}$ & 70.8 & 5 & $6.86 \mathrm{E}-14$ & 129.2 & 5 & $3.54 \mathrm{E}-26$ \\
\hline 2J vs CJ & 16.3 & 7 & $2.24 \mathrm{E}-02$ & 30.5 & 5 & $1.17 \mathrm{E}-05$ \\
\hline $5 S$ vs CS & 7.4 & 5 & $1.93 \mathrm{E}-01$ & 50.4 & 6 & $3.92 \mathrm{E}-09$ \\
\hline $2 \mathrm{~S}$ vs CS & 14.1 & 7 & $4.96 \mathrm{E}-02$ & 61.1 & 6 & $2.73 \mathrm{E}-11$ \\
\hline $2 \mathrm{~J}$ vs $2 \mathrm{~S}$ & 33.4 & 8 & $5.22 \mathrm{E}-05$ & 161.1 & 6 & $3.55 \mathrm{E}-32$ \\
\hline CJ vs CS & 9.9 & 5 & $7.80 \mathrm{E}-02$ & 37.8 & 5 & $4.08 \mathrm{E}-07$ \\
\hline $2 S$ vs $5 S$ & 7.8 & 5 & $1.65 \mathrm{E}-01$ & 12.9 & 6 & $4.42 \mathrm{E}-02$ \\
\hline
\end{tabular}

\section{References}

Bouchet, V.M.P., Alve, E., Rygg, B., Telford, R.J., 2012. Benthic foraminifera provide a promising tool for ecological quality assessment of marine waters. Ecol. Indic. 23, 66-75.

Bradshaw, J.S., 1957. Laboratory Studies on the Rate of Growth of the Foraminifer, “streblus Beccarii (linné) Var. Tepida (cushman)”. J. Paleontol. 31 (6), 1138-1147.

Brouwer, G.M., Wolthers, M., Hazeleger, J.H., Rossi, F., Lourens, L.J., Middelburg, J.J., Duijnstee, I.A.P., 2015. Differential response of intertidal foraminifera to ecosystem recovery succeeding experimentally induced hypoxia. J. Foraminifer Res. 45 (3), 220-234.

Buzas, M.A., 1978. Foraminifera as prey for benthic deposit feeders - results of predator exclusion experiments. J. Mar. Res. 36, 617-625.

Chandler, G., 1989. Foraminifera may structure meiobenthic communities. Oecologia 81 (3), 354-360.

Conley, D.J., Carstensen, J., Ærtebjerg, G., Christensen, P.B., Dalsgaard, T. Hansen, J.L.S., Josefson, A.B., 2007. Long-term changes and impacts of hypoxia in Danish coastal waters. Ecol. Appl. 17, 165-184.

Debenay, J., Bicchi, E., Goubert, E., 2006. Spatio-temporal distribution of benthic foraminifera in relation to estuarine dynamics (Vie estuary, Vendee, W France). Estuar. Coast. Shelf Sci. 67 (1-2), 181-197.

DeLaca, T.E., Karl, D.M., Lipps, J.H., 1981. Direct use of dissolved organic carbon by agglutinated benthic foraminifera. Nature 289, 287-289.

Denoyelle, M., Jorissen, F.J., Martin, D., Galgani, F., Miné, J., 2010. Comparison of benthic foraminifera and macrofaunal indicators of the impact of oil-based drill mud disposal. Mar. Pollut. Bull. 60, 2007-2021.

Diaz, R.J., Rosenberg, R., 2008. Spreading dead zones and consequences for marine ecosystems. Science 321, 926-929.

Diaz, R.J., Rosenberg, R., Rabalais, N.N., Levin, L.A., 2009. Dead zone dilemma. Mar. Pollut. Bull. 58, 1767-1768.

Duijnstee, I.A.P., De Nooijer, L.J., Ernst, S.R., Van der Zwaan, G.J., 2005. Population dynamics of benthic shallow-water foraminifera: effects of a simulated marine snow event. Mar. Ecol. Prog. Ser. 285, 29-42.

Ernst, S.R., Bours, R., Duijnstee, I.A.P., Van der Zwaan, G.J., 2005. Experimental effects of an organic matter pulse and oxygen depletion on a benthic foraminiferal shelf community. J. Foraminifer. Res. 35, 177-197.

Goldstein, S.T., 1999. Foraminifera: a biological overview. In: Sen Gupta, B.K. (Ed.), Modern Foraminifera. Kluwer Academic Publishers, Dordrecht, pp. 37-55.

Gray, J.S., Wu, R.S.S., Or, Y.Y., 2002. Effects of hypoxia and organic enrichment on the coastal marine environment. Mar. Ecol. Prog. Ser. 238, 249-279.

Gustafsson, M., Nordberg, K., 2000. Living (Stained) benthic foraminifera and their response to the seasonal hydrographic cycle, periodic hypoxia and to primary production in havstens fjord on the Swedish West Coast. Estuar. Coast. Shelf Sci. 51 (6), 743-761.

Josefson, A.B., Widbom, B., 1988. Differential response of benthic macrofauna and meiofauna to hypoxia in the Gullmar fjord basin. Mar. Biol. 100, 31-40.

Jorissen, F.J., de Stigter, H.C., Widmark, J.G.V., 1995. A conceptual model explaining benthic foraminiferal microhabitats. Mar. Micropaleontol. 26, 3-15.

Langezaal, A.M., Jannink, N.T., Pierson, E.S., Van der Zwaan, G.J., 2005. Foraminiferal selectivity towards bacteria: an experimental approach using a cell-permeant stain. J. Sea Res. 54, 256-275.

Langlet, D., Baal, C., Geslin, E., Metzger, E., Zuschin, M., Riedel, B., RisgaardPetersen, N., Stachowitsch, M., Jorissen, F.J., 2014. Foraminiferal species responses to in situ, experimentally induced anoxia in the Adriatic Sea. Biogeosciences 11, 1775-1797.

Lipps, J.H., 1983. Biotic Interactions in Benthic Foraminifera. In: Tevesz, M.J.S., McCall, P.J. (Eds.), Biotic Interactions in Recent and Fossil Benthic Communities. Plenum Press, New York, pp. 331-376. 
Middelburg, J.J., Barranguet, C., Boschker, H.T.S., Herman, P.M.J., Moens, T., Heip, C.H.R., 2000. The fate of intertidal microphytobenthos carbon: an in situ C-13-labeling study. Limnol. Oceanogr. 45, 1224-1234.

Middelburg, J.J., 2014. Stable isotopes dissect aquatic food webs from the top to the bottom. Biogeosciences 11, 2357-2371.

Mojtahid, M., Zubkov, M.V., Hartmann, M., 2011. Grazing of intertidal benthic foraminifera on bacteria: assessment using pulse-chase radiotracing. J. Exp. Mar. Biol. Ecol. 399 (1), 25-34.

Montserrat, F., Van Colen, C., Degraer, S., Ysebaert, T., Herman, P.M.J., 2008. Benthic community-mediated sediment dynamics. Mar. Ecol. Prog. Ser. 372, 43-59.

Montserrat, F., Van Colen, C., Provoost, P., Milla, M., Ponti, M., Van den Meersche, K. Ysebaert, T., Herman, P.M.J., 2009. Sediment segregation by biodiffusing bivalves. Estuar. Coast. Shelf Sci. 83, 379-391.

Moodley, L., Boschker, H.T.S., Middelburg, J.J., Pel, R., Herman, P.M.J., De Deckere, E., Heip, C.H.R., 2000. Ecological significance of benthic foraminifera: ${ }^{13} \mathrm{C}$ labelling experiments. Mar. Ecol. Prog. Ser. 202, 289-295.

Moodley, L., Middelburg, J., Boschker, H., 2002. Bacteria and foraminifera: key players in a short-term deep-sea benthic response to phytodetritus. Mar. Ecol. Prog. Ser. 236, 23-29.

Moodley, L., Van der Zwaan, G.J., Herman, P.M.J., Kempers, L., Van Breugel, P., 1997. Differential response of benthic meiofauna to anoxia with special reference to foraminifera (Protista: Sarcodina). Mar. Ecol. Prog. Ser. 158, 151-163.

Muller, W.A., Lee, J.J., 1969. Apparent indispensability of bacteria in foraminiferan nutrition. J. Protozool. 16 (3), 471-478.

Oakes, J.M., Eyre, B.D., Middelburg, J.J., 2012. Transformation and fate of microphytobenthos carbon in subtropical subtidal shallow sands: a ${ }^{13} \mathrm{C}$-labeling study. Limnol. Oceanogr. 57 (6), 1846-1856.

Parfrey, L.W., Katz, L.A., 2010. Genome dynamics are influenced by food source in Allogromia laticollaris strain CSH (Foraminifera). Genome Biol. Evol. 2, 678-685.

Pascal, P., Dupuy, C., Richard, P., Niquil, N., 2008. Bacterivory in the common foraminifer Ammonia tepida: isotope tracer experiment and the controlling factors. J. Exp. Mar. Biol. Ecol. 359, 55-61.

Rossi, F., Gribsholt, B., Middelburg, J.J., Heip, C., 2008. Context-dependent effects of suspension feeding on intertidal ecosystem functioning. Mar. Ecol. Prog. Ser. 354, 47-57.

Rossi, F., Middelburg, J.J., 2011. Intraspecific diet shift of Macoma balthica during community reassembly in an estuarine intertidal flat. Estuar. Coast. Shelf Sci. 92, 496-501.
Rossi, F., Vos, M., Middelburg, J.J., 2009. Species identity, diversity and microbial carbon flow in reassembling macrobenthic communities. Oikos 118, 503-512.

Schönfeld, J., Alve, E., Geslin, E., Jorissen, F.J., Korsun, S., Spezzaferri, S., 2012. The FOBIMO (FOraminiferal Blo-MOnitoring) initiative-towards a standardised protocol for soft-bottom benthic foraminiferal monitoring studies. Mar. Micropaleontol. 94, 1-13.

Small, C., Nicholls, R., 2003. A global analysis of human settlement in coastal zones. J. Coast. Res. 19 (3), 584-599.

Strotz, L.C., 2015. Spatial patterns and diversity of foraminifera from an intermittently closed and open lagoon, Smiths Lake, Australia. Estuar. Coast. Shelf Sci. $164,340-352$.

Van Colen, C., Montserrat, F., Vincx, M., Herman, P.M.J., Ysebaert, T., Degraer, S., 2008. Macrobenthic recovery from hypoxia in an estuarine tidal mudflat. Mar. Ecol. Prog. Ser. 372, 31-42.

Van Colen, C., Montserrat, F., Verbist, K., Vincx, M., Steyaert, M., Vanaverbeke, J., Herman, P.M.J., Degraer, S., Ysebaert, T., 2009. Tidal flat nematode responses to hypoxia and subsequent macrofauna-mediated alterations of sediment properties. Mar. Ecol. Prog. Ser. 381, 189-197.

Van Colen, C., Montserrat, F., Vincx, M., Herman, P.M., Ysebaert, T., Degraer, S. 2010a. Long-term divergent tidal flat benthic community recovery following hypoxia-induced mortality. Mar. Pollut. Bull. 60, 178-186.

Van Colen, C., Montserrat, F., Vincx, M., Herman, P.M.J., Ysebaert, T., Degraer, S., 2010b. Macrobenthos recruitment success in a tidal flat: feeding trait dependent effects of disturbance history. J. Exp. Mar. Biol. Ecol. 385, 79-84.

Van Colen, C., Rossi, F., Montserrat, F., Andersson, M.G.I., Gribsholt, B., et al., 2012. Organism-sediment interactions govern post-hypoxia recovery of ecosystem functioning. PLoS One 7 (11), 49795.

Van der Zwaan, G.J., Duijnstee, I.A.P., den Dulk, M., Ernst, S.R., Jannik, N.T., Kouwenhoven, T.J., 1999. Benthic foraminifers: proxies or problems? A review of paleocological concepts. Earth Sci. Rev. 46, 213-236.

Van Oevelen, D., Moodley, L., Soetaert, K., Middelburg, J.J., 2006. The trophic significance of bacterial carbon in a marine intertidal sediment: results of an in situ stable isotope labeling study. Limnol. Oceanogr. 51 (5), 2349-2359.

Zhang, H., Ludsin, S.A., Mason, D.M., Adamack, A.T., Brandt, S.B., Zhang, X., Kimmel, D.G., Roman, M.R., Boicourt, W.C., 2009. Hypoxia-driven changes in the behavior and spatial distribution of pelagic fish and mesozooplankton in the northern gulf of Mexico. J. Exp. Mar. Biol. Ecol. 381, 80-91. 